\title{
Inheritance of Resistance to Three Races of Fusarium oxysporum f. sp. adzukicola in Adzuki Bean Cultivars
}

\author{
Norio Kondo*, Kippei Murata**, Hisanori ShimadA***, \\ Shigehisa SHIRAI*** and Fujio Kodama*
}

\begin{abstract}
Key words: adzuki bean, resistance inheritance, Fusarium oxysporum f. sp. adzukicola,
\end{abstract} race.

In a pervious report ${ }^{1)}$ we identified three races of Fusarium oxysporum f. sp. adzukicola, which causes a wilt disease of adzuki bean (Vigna anguriaris (Willd.) Ohwi et Ohashi), and suggested the following cultivars to be used as differentials to identify these three races: Toiku No. 123 (resistant to all three races), Hatsune-shozu (resistant to race 1 and race 2) and Hikarishozu (resistant to only race 1). In this study we report the results of investigations to determine the mode of inheritance of resistance in Toiku No. 123 and Hatsune-shozu to these three races.

Cultivar Buchishoryukei-1, which is susceptible to all three races of the pathogen, was used as the male parent in this study. Fortunately, this cultivar has an incomplete dominant gene ${ }^{3)}$ showing phenotypically characteristic pigmentation of the stem, petiole, and seed coat, which distinguishes it from the recessive phenotype. Consequently, we were able to determine if crosses had succeeded. Toiku No. 123 is a derivative of Erimo-shozu $\times$ Shochohin-10 (unpublished), and Hatsune-shozu resulted from Hayate-shozu $\times$ Akamame $^{2}$. The progenies derived from crosses with these two cultivars used as female parents were used to determine the inheritance of resistance.

Parents, $F_{1}$, and $F_{2}$ progenies were inoculated with isolate KF646 as race 1, isolate KF654 as race 2, and isolate KF843 as race 3 of $F$. oxysporum f. sp. adzukicola using a seedling root dip inoculation procedure.

The inoculum was produced on potato sucrose agar (PSA) plates incubated at $25 \mathrm{C}$ for 3 weeks. The spores were suspended in distilled water and the suspension passed through four layers of cheesecloth, centrifuged at 3,500 rpm, and the pellet was then resuspended in distilled water. Seedlings were grown in sterilized vermiculite until the primary leaves were fully expanded (about 7 to 10 days), then they were removed from the vermiculite and their root system was washed gently. They were then dipped for $1 \mathrm{hr}$ in a suspension of spores (adjusted to $10^{6}$ microconidia $/ \mathrm{ml})$ and then transplanted into boxes $(25 \times 50 \times 10 \mathrm{~cm})$ filled with sterilized soil. Plants were grown in the greenhouse at $15-30 \mathrm{C}$.

Results were recorded after 40 days and the reaction of individual plants was scored using a disease severity rating (DSR) of 1 to $10^{3}: 1=$ healthy, no external symptoms and no vascular

* Hokkaido Central Agricultural Experiment Station, Naganuma, Hokkaido 069-13, Japan 北海 道立中央農業試験場

** Tohoku National Agricultural Experiment Station, Nishisenpoku, Akita 019-21, Japan 東北 農業試験場

*** Hokkaido Prefectural Tokachi Agricultural Experiment Station, Memuro, Hokkaido 082, Japan 北海道立十勝農業試験場

1) Kondo, N. and Kodama, F. (1989). Ann. Phytopath. Soc. Japan 55: 451-457. 2) Adachi, T., Narikawa, T., Chiba, I., Murata, K., Hara, M. and Shimada, H. (1988). Bull. Hokkaido Prefect. Agric. Exp. Stn. 57: 13-24. 3) Takahashi, Y. and Fukuyama, J. (1917). Hokkaido National Agric. Exp.

Stn. Rep. 7: 128-131. 
discoloration; $10=$ vascular discoloration, but no external symptoms; $10^{2}=$ leaf necrosis, stunting or wilting; $10^{3}=$ plants were dead. Plants with a DSR of 1 or 10 were rated resistant whereas those with a DSR of $10^{2}$ or $10^{3}$ were rated susceptible. The disease severity index (DSI) was calculated from the formula: DSI $=\log [\operatorname{mean}(\mathrm{DSR})]$.

Cultivars Hatsune-shozu (DSI $=0.40$ and 0.49 to race 1 and race 2, respectively) and Toiku No. 123 (DSI = 0.22 and 0.11) were resistant and Buchishoryukei-1 (DSI = 2.70 and 2.98) was susceptible to race 1 and race 2 (Table 1 and Table 2). Cultivar Toiku No. 123 (DSI=0.21) was resistant and Hatsune-shozu (DSI=1.53) and Buchishoryukei-1 (DSI=3.00) were susceptible to race 3 (Table 3). These results were similar to those reported previously ${ }^{1}$. Although not all of the $F_{1}$ progenies of Hatsune-shozu $\times$ Buchishoryukei-1 were classified as susceptible to race $1(\mathrm{DSI}=1.52)$ and race $2(\mathrm{DSI}=1.91)$, the $\mathrm{F}_{2}$ segregated in a ratio of $1 \mathrm{R}: 3 \mathrm{~S}$, indicating that resistance is recessive (Table 1 and Table 2). On the other hand, the reaction of the $F_{1}$ progenies of Toiku No. $123 \times$ Buchishoryukei-1 indicated complete dominance for resistance to race $1(\mathrm{DSI}=0.10)$, race $2(\mathrm{DSI}=0.45)$, and race $3(\mathrm{DSI}=0.75)$. The segregation ratios of the $F_{2}$ progenies also show that one dominant gene controls resistance (Tables 1, 2 and 3).

We classified cultivar Hatsune-shozu as susceptible to race 3. However, Hatsune-shozu was less susceptible to race $3(\mathrm{DSI}=1.53)$ than was Buchishoryukei-1 $(\mathrm{DSI}=3.00)$. This suggests that this cultivar may have an intermediate level of resistance. Therefore, another modifying gene (or genes) may be involved with resistance of Hatsune-shozu, in addition to a recessive

Table 1. Inheritance of resistance to Fusarium oxysporum f. sp. adzukicola race 1 in progenies of crosses between resistant and susceptible adzuki bean cultivars

\begin{tabular}{|c|c|c|c|c|c|c|}
\hline \multirow{2}{*}{ Cultivar and cross } & \multirow{2}{*}{$\begin{array}{l}\text { Plants } \\
\text { tested } \\
\text { (No.) }\end{array}$} & \multirow{2}{*}{$\begin{array}{l}\text { Expected } \\
\text { ratio }\end{array}$} & \multicolumn{2}{|c|}{ Observed } & \multirow{2}{*}{$\begin{array}{c}\chi^{2} \\
\text { value }\end{array}$} & \multirow{2}{*}{$P$} \\
\hline & & & $R_{\text {a) }}$ & $\mathrm{S}$ & & \\
\hline Hatsune-shozu (HAT) & 30 & All R & 30 & 0 & - & - \\
\hline Toiku No. 123 (123) & 27 & All R & 27 & 0 & - & - \\
\hline Buchishoryukei-1 (BS1) & 30 & All S & 0 & 30 & - & - \\
\hline \multicolumn{7}{|l|}{$\mathrm{HAT} \times \mathrm{BS} 1$} \\
\hline$F_{1}$ & 14 & All $\mathrm{S}$ & 10 & 4 & - & - \\
\hline $\mathrm{F}_{2}$ & 120 & $1 \mathrm{R}: 3 \mathrm{~S}$ & 31 & 89 & 0.04 & $0.80-0.90$ \\
\hline \multicolumn{7}{|l|}{$123 \times$ BS 1} \\
\hline$F_{1}$ & 33 & All R & 33 & 0 & - & - \\
\hline $\mathrm{F}_{2}$ & 68 & $3 \mathrm{R}: 1 \mathrm{~S}$ & 52 & 16 & 0.08 & $0.70-0.80$ \\
\hline
\end{tabular}

a) R: resistant, $\mathrm{S}$ : susceptible.

Table 2. Inheritance of resistance to Fusarium oxysporum f. sp. adzukicola race 2 in progenies of crosses between resistant and susceptible adzuki bean cultivars

\begin{tabular}{|c|c|c|c|c|c|c|}
\hline \multirow{2}{*}{ Cultivar and cross } & \multirow{2}{*}{$\begin{array}{l}\text { Plants } \\
\text { tested } \\
\text { (No.) }\end{array}$} & \multirow{2}{*}{$\begin{array}{l}\text { Expected } \\
\text { ratio }\end{array}$} & \multicolumn{2}{|c|}{ Observed } & \multirow{2}{*}{$\begin{array}{c}\chi^{2} \\
\text { value }\end{array}$} & \multirow{2}{*}{$P$} \\
\hline & & & $R$ a) & $\mathrm{S}$ & & \\
\hline Hatsune-shozu (HAT) & 30 & All $\mathrm{R}$ & 30 & 0 & - & - \\
\hline Toiku No. 123 (123) & 30 & All R & 30 & 0 & - & - \\
\hline Buchishoryukei-1 (BS1) & 30 & All $\mathrm{S}$ & 0 & 30 & - & - \\
\hline \multicolumn{7}{|l|}{ HAT $\times$ BS 1} \\
\hline$F_{1}$ & 16 & All S & 3 & 13 & - & - \\
\hline $\begin{array}{c}F_{2} \\
123 \times B S 1\end{array}$ & 99 & $1 \mathrm{R}: 3 \mathrm{~S}$ & 27 & 72 & 0.27 & $0.50-0.70$ \\
\hline $\mathrm{F}_{1}$ & 30 & All $\mathrm{R}$ & 30 & 0 & - & - \\
\hline $\mathrm{F}_{2}$ & 132 & $3 \mathrm{R}: 1 \mathrm{~S}$ & 102 & 30 & 0.36 & $0.50-0.70$ \\
\hline
\end{tabular}

a) R: resistant, $\mathrm{S}$ : susceptible. 
Table 3. Inheritance of resistance to Fusarium oxysporum f. sp. adzukicola race 3 in progenies of crosses between resistant and susceptible adzuki bean cultivars

\begin{tabular}{|c|c|c|c|c|c|c|}
\hline \multirow{2}{*}{ Cultivar and cross } & \multirow{2}{*}{$\begin{array}{l}\text { Plants } \\
\text { tested } \\
\text { (No.) }\end{array}$} & \multirow{2}{*}{$\begin{array}{l}\text { Expected } \\
\text { ratio }\end{array}$} & \multicolumn{2}{|c|}{ Observed } & \multirow{2}{*}{$\begin{array}{c}\chi^{2} \\
\text { value }\end{array}$} & \multirow{2}{*}{$P$} \\
\hline & & & $R$ a) & $S$ & & \\
\hline Hatsune-shozu (HAT) & 30 & All S & 21 & 9 & - & - \\
\hline Toiku No. 123 (123) & 30 & All R & 30 & 0 & - & 一 \\
\hline Buchishoryukei-1 (BS1) & 30 & All S & 0 & 30 & - & - \\
\hline \multicolumn{7}{|l|}{$\mathrm{HAT} \times \mathrm{BS} 1$} \\
\hline $\begin{array}{c}\mathrm{F}_{2} \\
123 \times \mathrm{BS} 1\end{array}$ & 120 & All $\mathrm{S}$ & 7 & 113 & - & - \\
\hline$F_{1}$ & 31 & All R & 31 & 0 & - & - \\
\hline $\mathrm{F}_{2}$ & 213 & $3 \mathrm{R}: 1 \mathrm{~S}$ & 165 & 48 & 0.69 & $0.30-0.50$ \\
\hline
\end{tabular}

a) $\mathrm{R}$ : resistant, $\mathrm{S}$ : susceptible.

gene.

Based upon the reaction of adzuki bean cultivars and lines ${ }^{1)}$ to the three races (Cultivars Erimo-shozu and Hayate-shozu were susceptible to all races), it is apparent that the recessive gene of Hatsune-shozu was derived from Akamame, which originated in Korea, and the dominant gene to Toiku No. 123 was derived from Shochohin-10, which was originally cultivated in Nagano Prefecture in the middle part of Japan. In addition, the fact that Akamame was resistant to race 3 also suggests that Akamame has both the recessive gene (resistant to race 2) and the dominant gene (resistant to race 3).

Gene symbols are not being proposed for the resistance genes to $F$. o. f. sp. adzukicola race 1 , race 2, and race 3 because the inheritance of resistance to race 1 in Hikari-shozu was not clear and the nature of the association among these genes was not determined.

The authors wish to thank Dr. J.E. Hunter, Professor of Cornel University, for critical reading of the manuscript.

\section{和 文 摘 要}

近藤則夫・村田吉平・島田尚典・白井滋久・児玉不二雄 : アズキ品種のアズキ萎ちょら病抵抗性遺伝子分 析

アズキ萎ちょう病菌（Fusarium oxysporum f. sp. adzukicola) レース 1,2 亿抵抗性の「ハッネショウズ」 とレース 1,2,3 に抵抗性の「十育 123 号」それぞれと, 罹病性品種の「斑小粒系-1」との $\mathrm{F}_{1}, \mathrm{~F}_{2}$ の各レ 一スに対する反応から抵抗性の遺伝子分析を行った。その結果, 「ハッネショウズ」のレース 1,2 に対する 抵抗性は 1 対の劣性遺伝子に,「十育 123 号」のレース $1,2,3$ に対する抵抗性は 1 対の優性遺伝子に支 配されていることが明らかになった。 